\title{
From Rigging to Violence
}

Mapping of political regression

\section{Bernard Calas}

\section{(2) OpenEdition}

\section{Journals}

Electronic version

URL: https://journals.openedition.org/eastafrica/713

DOI: 10.4000/eastafrica. 713

ISSN: 2790-1076

\section{Publisher}

IFRA - Institut Français de Recherche en Afrique

\section{Printed version}

Date of publication: 1 April 2008

Number of pages: 171-192

ISSN: 2071-7245

\section{Electronic reference}

Bernard Calas, "From Rigging to Violence", Les Cahiers d'Afrique de l'Est / The East African Review [Online], 38 | 2008, Online since 18 July 2019, connection on 09 December 2021. URL: http:// journals.openedition.org/eastafrica/713 ; DOl: https://doi.org/10.4000/eastafrica.713

This text was automatically generated on 9 December 2021

Les Cahiers d'Afrique de l'Est / The East African Review 


\title{
From Rigging to Violence
}

\author{
Mapping of political regression
}

\author{
Bernard Calas
}

1 Mapping of the elections and the post-election violence which took place in Kenya at the beginning of 2008 allows certain parties to initially qualify it through an analysis that combines both ethnicity and violence. The ethnicising of violence does not seem to be clear while the localization of violence in the country is more often a result of land issues rather than direct ethnic antagonism. In contrast, crime in urban areas has taken on the form of unequivocal ethnicisation.

2 On 27 December 2007, the 14 million Kenyans registered on the voters' roll were called upon to vote three times, casting three different ballot papers in three separate ballot boxes to elect their President, one of their 210 MPs and their local councillor. ${ }^{1}$ The main presidential candidates were the incumbent Mwai Kibaki, opposition leader Raila Odinga-son of the father of opposition, Oginga Odinga-and their challenger Kalonzo Musyoka. The importance of ethnic identification in electoral allegiance and choice as well as in the Western view of African politics makes a compelling case to state from the offset that the first candidate is a Kikuyu from Central Province, the second a Luo from Nyanza Province and the third one is a Kamba from the south of Eastern Province.

The main stake in this election was whether voters would re-elect Kibaki, who had brought great hope to the 2002 elections. During his term in office, there was disillusionment over his aspiration to new politics, improve social and economic conditions of the majority and inject morals into political life, especially due to a maintained high level of corruption and worsening inequalities as the country experienced rapid economic growth. As early as during the 2005 constitutional referendum, which the opposition-backed "No" campaign won, voters had opted to punish the disappointing government personified by an ageing and a stuttering president. $^{2}$ The second stake in these elections was whether parliamentary elections would determine the presidential choice, giving the President a parliamentary majority. Three parties, or rather three nebulous supporters were in the race: Orange Democratic Movement (ODM) behind Raila Odinga, Party for National Unity (PNU) behind Mwai Kibaki and ODM-Kenya (ODM-K) behind Musyoka. 
The three phases of the Kenyan crisis-voting, violence and socio-spatial adjustmentsconstitute an event which refutes the idea that Kenya since the 2002 elections, Kenya had opened up a new chapter of "democrazy" (characterized by failed elections, sealed with political and ethnic violence and political manipulation of the second period of the Moi era) to become an "emerging democracy." Furthermore, one may wonder whether the January-February 2008 "events" were a political split with lasting consequences or whether they are as old as Kenyan politics, periodically rocked by violent fluctuations. An attempt to answer this question amounts to interpreting the meaning of the events with regard to the past and in the light of socio-spatial developments which it entails. Secondly, a parallel will be drawn to electoral mapping and violence mapping that followed the elections, in order to attempt to establish spatial figures, which, although being temporary and partial, is indispensable.

\section{Sketch mapping of the electorate}

Generally speaking, voter turnout was $70 \%$ and there was no significant difference in the turnout for the three elections, although the turnout for the presidential election was slightly higher, either due to rigging or due to higher stakes. The highest turnout (high figures between $85 \%$ and $95 \%$, which undoubtedly indicated rigging) was registered along the shores of Lake Victoria-in Luoland, and in the western parts of Central Province, in Kikuyu land. The lowest turnout was registered in the largest urban centres, Nairobi, Mombasa and Nakuru. Most of the other constituencies registered low voter turnout between $60 \%$ and $70 \%$. An analysis of the meaning of the turnout is rendered difficult by rigging and the difficulty in pinning this down. The election rigging, which was massive, was however, neither systematic nor unilateral and it cannot be said for sure that this altered the final result of the presidential election apart from further delegitimizing government, politics and the regime in the eyes of Kenyans. The frauds particularly wanted to influence the result of the presidential poll whose stakes were a determining factor on the entire general election.

6 Four main types of irregularities can be identified. The first three occurred mainly outside Nairobi and influenced the results at the local level while the fourth one took place in Nairobi at the Kenyatta International Conference Centre (KICC) tallying centre. This latter influenced the national outcome of the presidential poll. The first type of irregularity took place during the voter registration exercise; as a result, there were up to $15 \%$ dead voters registered in the roll. ${ }^{3}$ The second type of electoral fraud took place in ethnically homogenous constituencies. Inflated results brought the voter turnout to figures higher than $100 \% .{ }^{4}$ In constituencies with low levels of literacy, on the fringes of "arable Kenya" (Coast and North-Eastern provinces, Maasailand, North Rift), there were suspicions of ODM poll agents being compromised by government agents and massive vote-buying was reported. ${ }^{5}$ Finally, some results were altered, sometimes clumsily, during transportation between local polling stations and the national tallying centre and collation of results at KICC. ${ }^{6}$ These irregularities had the heaviest impact on the final result of the presidential poll. By 30 December 2007, ODM and PNU observers at KICC unanimously agreed that the irregularities affected 44 constituencies. The irregularities occurred mostly in the country's most populous districts as the map in the annex shows. There is a possibility that all the irregularities influenced $3 \%$ per cent 
of the vote while the margin separating Kibaki and Odinga, giving victory to the former, was at least 232,000 votes, an equivalent of $2.3 \%$ of the votes cast.

7 Since the electoral fraud influenced the presidential poll result, the parliamentary elections seemed to be a better reflection of public opinion. A total of 207 MPs were named (elections in three constituencies having been cancelled) and on 15 January during the election of the National Assembly Speaker, 105 MPs carried the day after three rounds of voting in favour of the ODM candidate, Kenneth Marende. Beyond this short-lived victory for ODM, the elections appeared to totally overhaul the political class and dismissed more than half of the incumbent MPs. To an extent, one could say there was a real generational transition and new political landscape in Kenya. Younger people, newcomers and women emerged at the expense of a long list of old hands in politics (such as Nicholas Biwott and Simeon Nyachae) and descendants of prestigious political dynasties (including the three sons of former President Moi, who all lost). However, some of the newly elected were not political novices since them were in fact losers in the 2002 elections. Therefore, even though the impression of overhaul was real, it remained to be qualified. This development took place in all regions and it was as true to ODM as to PNU. Thus in north Rift, the protest vote wave swept in 12 new faces in 19 constituencies ( $N$. Biwott, former third in command and Minister for energy in the Moi regime, was defeated by a 38 year-old). In Central Province, ministers who enjoyed support from leading figures like Lucy Kibaki (the president's wife), including John Michuki, also lost. This also affected opposition barons in Luoland, along the coast and in Kisiiland.

8 The partisan allegiance of the elected leaders seemed to be along real regional bastions and pointed to an ethnic poll. Indeed, the map of the parliamentary election results showed contours of three consistent and relatively ethno-politically homogenous spaces: western (virtually Luo) ODM, central (virtually Kikuyu) PNU and allies, as well as central-eastern (virtually Kamba) ODM-K. For their part, Nairobi and Mombasa cities largely voted ODM.

However, talking about ethnic votes is both accurate and somewhat simplistic. Beyond the presidential electoral fraud, Kibaki harvested nearly $50 \%$ of the votes while the Kikuyu ( 7 million) are only $22 \%$ of the population. This means that more than half of his electors were not Kikuyu. Their neighbours in Mount Kenya, the Embu and Meru ( 2 million or $5 \%$ of the Kenyan population) are allies of the Kikuyu. Generally, it can be said that despite the Kikuyu voting overwhelmingly for Kibaki, all those who voted for Kibaki were not Kikuyu. A similar logic applies to Odinga. The Luo are only $13 \%$ of the Kenyan population yet Odinga garnered almost $50 \%$ of the vote. Although the Luo voted overwhelmingly for ODM, not all those who voted ODM were Luo.

The analysis according to coherent and solid political blocs could also prove to be an illusion. Indeed, the ODM, and to a larger extent, the presidential coalition around PNU and even ODM-K, were fragile and volatile outfits. The nomination and primary polls episode was significant in this matter. In October-November 2007, the parties held primaries to nominate their parliamentary candidates. Apart from some targeted incidents of violence, particularly against candidates, these primaries gave rise to a real musical chain of party allegiance. Some politicians changed parties several times because they had been denied nomination. This was proof of how unreliable party membership was and one could switch very quickly depending on the circumstances. The idea that the opposition could rely on its parliamentary majority to impede the 
president's initiative appeared even more unrealistic because ten of the newly-elected MPs from western Kenya belonged to NARC (National Rainbow Coalition - Kenya), President Kibaki's party until PNU was formed and they would obviously be under intense pressure from the presidential camp to "cross the floor." The about-turn of the second runner-up in the presidential poll, K. Musyoka, who suddenly swore allegiance to the government by accepting the vice-president's post in January, only confirmed this view of Kenyan politics, for the least "pragmatic." The revolt by ODM-K officials during the nomination of MPs (10 MPs are nominated by the president just before the opening of the first parliamentary session after they are proposed by party leaders and according to the party's strength in parliament) confirmed this serious instability within political parties. They are vulnerable to break-ups at the slightest excuse or pressure (corruption, threats...). In reality, the spatial distribution of votes emphasizes the combination of several factors which contributed to the ODM wave and the resistance to a consequent bloc brought about by the alliance between PNU and ODM-K.

The identity vote inevitably played out in Luo, Kikuyu and Kamba land. Indeed, each of the three main political leaders in the election, Kibaki, Odinga and Musyoka-as well as their parties-PNU and its affiliate parties, ODM and ODM-K, won in the respective regions. The consistency between the presidential poll, party allegiance, high voter turnout, constituency contours and ethnic identity make it possible to talk about electoral strongholds and even political territories.

In the Western Province, Luhyaland and in Meru and Embu, Eastern Province, it is evident from the voting patterns that the process was more regional than identitylinked. In fact, what led the Luhya to vote for Odinga and ODM while the Embu and Meru voted for Kibaki and the PNU was the feeling of a community socio-spatial exclusion concerning the Luos, and on the other, the convergence of interests and history concerning the Kikuyu. The feeling is certainly partly underpinned by the spatial unity between the two sides.

The protest and generational vote, which was higher in urban centre played out in favour of the Orange Party. The support of a large number of Nairobi youth-especially in Nairobi Eastlands slums like Embakasi, which is largely but not exclusively inhabited by the Kikuyu-explains ODM's success in six out of the capital's eight constituencies. The same line of reasoning explains the extent of Orange victory in Mombasa.

Ulterior motives over land played out elsewhere, especially in the Rift Valley. Here, the desire to prevent the president, who was perceived as the potential bearer of a threat over land, from remaining in office, was one of the main reasons the Kalenjin people voted ODM. This over-determination of the vote by old land stakes explains the failure of the marriage of convenience between Moi and Kibaki. ${ }^{8}$ Indeed, this alliance was based on the idea that Moi's support to Kibaki would be enough to placate Kalenjins over Kibaki's ethnic origin. Kalenjins are the majority in west and north Rift and consider the Kikuyu, led by the(ir) President, as land grabbers. However, Odinga garnered $65 \%$ of the vote in the Rift Valley (against Kibaki's 33\%) and 31 out of the 49 parliamentary seats went Orange. In return, on the Laikipia plateau, the pioneer front of Kikuyu settlers, ${ }^{9}$ in Naivasha, Oloitoktok and Kajiado districts, in eastern central Rift Valley, the fear of losing recently acquired land and the identity reflex favored the Kibaki vote and the election of pro-government candidates. 
16 Finally, in Coast Province, the debate around majimbo (which should be understood not as "federalism" but as "regional preference")-explicitly advocated for by Odinga and equally criticized by Kibaki-was at the core of the campaigns and the voting. ${ }^{10}$ In this region, the MoU signed between Odinga and the Muslims during the campaigns also contributed to rallying some voters in support of ODM. ${ }^{11}$ But the majimbo issue played out differently elsewhere, especially in the Rift Valley and in North-Eastern Province where it was seen as a means of evicting non-native minorities, particularly the Kikuyu. In a number of areas, the generational dimension of the election was finally expressed clearly. Thus, in Kisii land, where the same number of MPs was elected on both sides, scenes of violence during riots at the beginning of January involved pro-ODM youths hunting down and threatening their elders whom they blamed for supporting Kibaki, considered a dishonest elder.

On the whole, support for Odinga and for his pro-majimbo political plan-the only real stumbling block between the two parties-the rejection of Kibaki and his government ("We will punish him") and the identity proximity ("He is from among us") were the main driving forces in the electoral choice.

\section{History and geography of post-election violence}

19 The results of the elections were still unknown towards the end of December 2007 when the delay in tallying and growing rumours of rigging triggered off an escalation of violence. These events were relayed by the media to the Western world as the New Year was ushered in..$^{12}$ Two months later, these events resulted in 1,000 deaths and 300,000 IDPs, according to official figures. The mapping of the violence largely arise from the same logic as the violence, which can be identified by isolating the various phases from which the violence developed from the end of December 2007 and the end of February 2008.

First, between the end of December and mid-January, postelection frustration was vented in riots that inflamed constituencies that the opposition had won: Luoland, especially its capital Kisumu, Mombasa and parts of Nairobi inhabited by the Luo, starting with the sprawling Kibera slums, and to a lesser extent Kawangware slums, and some pockets in Mathare slums in the east of the capital. Between Nakuru and Eldoret, especially around Turbo and Timboroa, and the rural areas within the Eldoret-NakuruKericho triangle, the violence took the form of peasant uprising, which was undoubtedly course stage-managed by local politicians and prominent figures..$^{13}$ The violence first targeted Kikuyu minorities and to a lesser extent the Kisii minorities. However, while in Kisumu spontaneous riots led to the destruction of entire streets without a single loss of life (the violent deaths were caused by a disproportionate reaction of the security forces in clashes that lacked the ethnic dimension), pogroms and uprisings elsewhere were accompanied by violent deaths. A case in point is the arson attack on a church in Kiambaa, an area in Eldoret, where about 30 people met their death. ${ }^{14}$

21 Nevertheless, contrary to what the international media led the world to believe, not the whole country was in a state of unrest. Riots, looting and murders mainly took place in areas with high population density: western Kenya, mainly in Luoland, settlement schemes in former White settler highlands of the Rift Valley, ${ }^{15}$ some parts of the intra- 
urban slums (and not the populous slums in the outskirts) and their immediate neighbourhoods in Mombasa and especially Nairobi. An assessment of this as a reversal of the security map-usually it is the regions in north-eastern and northern Kenya that are reputed for insecurity-would be attractive if the localized nature of the violence was not so clear. Thus, in Kibera for example $\left(700,000\right.$ residents on $\left.10 \mathrm{~km}^{2}\right)$, where the violence received most media coverage, the Soweto 5 and Lindi sections were not affected by any violence. Similarly, although there clashes pitting gangs from poor sections like Kisumu Ndogo, Katwekera and Kianda against militias from estates like Olympic, Ayany and Fort Jesus, the neighbouring Karanja estate, which is inhabited by the small well-organized minority Nubians (descendants of Sudanese soldiers who served in the colonial army) was spared from chaos; the rest of the sprawling slum also remained calm. These events of the second half of January 2008 shows the slide of political violence into social violence with criminal actors, gangs that were prompt in taking advantage of the slightest lapse in vigilance of the police to operate in broad daylight. This descent in some cases began as early as the beginning of January.

In the third phase, from the end of January 2008, urban riots in Kisumu and Nairobi gradually died down and the violence was transferred to other areas where different ethnic communities cohabited; Nakuru town (25 January) and its suburbs, then the Naivasha horticultural belt (27 January) and finally the north-western suburb of Nairobi (29 January) and the large coffee plantations in Central Province. In these areas, the violence was in the form of targeted revenge against minorities from western parts of the country, which was instigated by some Kikuyu politicians, with the support of militias like Mungiki ${ }^{16}$ among others. The horticultural farms in Naivasha, the Kenya Agricultural Research Institute laboratories in the outskirts of Nairobi and the Kenya Forestry Research Institute in Muguga, were targeted for ethnic cleansing. ${ }^{17}$ This organized violence coincided with the assassination of two opposition MPs-Embakasi and Eldoret South. The latter was killed by a policeman claiming to be the husband of his concubine $!^{18}$ These also coincided with personal threats against some of the most visible human rights activists. All these happened while talks to resolve the crisis between the government and the opposition continued in the Kenyan capital under the chairmanship of Kofi Annan.

During the entire period, clashes between peasant communities persisted and spread to the Nakuru-Eldoret-Kericho triangle, albeit in a more localized manner. These were mainly triggered by Kalenjins (mainly Nandis and Kipsigis) often degenerating into border battles, resulting in clashes over administrative borders between cosmopolitan districts. This was very clear between Kisii and Kalenjin land.

Therefore, the violence did not have the same modalities everywhere or at the same time. Behind the settling of scores, intimidation and police overzealousness, which were seemingly intentional (a good number of dead bodies had bullet wounds on the back ${ }^{19}$ ), there was a mixture of political exasperation and xenophobia mainly targeting minority groups considered "outsiders." 20

In urban centres, violence affected small traders, especially the Kikuyu, while in the rural areas, its target was small "outsider" land owners. First, the violence was accompanied by looting and secondly, it involved destroying homes of "outsiders," who in some cases had been residents since the 1960s. This was aimed at reducing their title deeds and discouraging them from ever returning. The relationship between the victims and their aggressors were different depending on whether the violence 
occurred in urban centres or rural areas, but in the rural areas, what was often shocking was that the attackers knew the people they had targeted. In many cases, these were their neighbours of longstanding. It was difficult to avoid drawing similarities with the violent episodes that rocked countries in the Congo-Nile crest, Rwanda and Burundi. In campaigns carried out in western parts of the Rift Valley, "Kalenjin" warriors, who swung into action with some degree of preparation and consultation, triggered the violence. These militias sometimes occupied towns-Eldoret for example-police stations, schools and churches, where their targets took refuge.

Initially, in the urban centres, the violence was often spontaneous, with the hallmarks of political riots. These brought together groups of young men. Secondly, the violence often involved sects or gangs, which sometimes carried out serious, highly localized ethnic cleansing, especially in Mathare. For a change, in a departure from what happened in 1982 and 1990, the central district of Nairobi did not experience any destruction. Despite employers' fears and traffic jams (linked more to lack of means of transport and police roadblocks than to the violence itself), life went on normally for the whole of the crisis period. Thus, many decades of urban segregation, police tactics and election strategies confined the violence to the poor districts.

\section{Territorial consequences of the post-election violence}

The immediate effect of the violence was the suspension of economic activity which had already slowed down during the vacation period at the end of the year. ${ }^{21}$ The violence compartmentalized space, reduced mobility, left the streets and especially the markets empty. The streets were abandoned for security forces while markets were at the mercy of looters and traders' militias. The constrained mobility was one of the consequences of the crisis. On the roads, there was an increase in the number of barriers erected by vigilantes or by the police, which were turned into toll stations and roadblocks, ${ }^{22}$ points for predatory activities and targeted violence. These barriers divided the country into two mobility spaces: on the one hand, the east, where there was normal movement, and on the other hand, the west, towards which all movement was virtually banned, especially for transporters identified as Kikuyu. This led Ugandan entrepreneurs, whose access to the sea had been cut off, to insist that the Kenyan government secures the Mombasa-Nairobi-Nakuru-Malaba-Busia corridor. These road barriers mobilized young rebels, who seemed to be insensitive to calls for calm by their elders and local political leaders.

On 15 January 2008, 250,000 people were classified as internally displaced and received at police posts, schools, show grounds and stadia while 6,000 others, three quarters of which were Kikuyus, fled to Uganda for refuge. At the beginning of February, following the revenge attacks around Naivasha, the Kenya Red Cross Society placed the figure of internally displaced people at 300,000. They had been offered shelter at police stations, prisons, some schools and missions, and in make-shift camps. Out of these 300,000 internally displaced people, 21,000 were based at the Eldoret camp set up at the show ground, 37,000 were based at the four camps in Kitale, 42,000 were based in the Molo camp, 52,000 in Nakuru and 16,000 in Naivasha. By the end of February, the Red Cross estimations were 270,000 internally displaced in camps and 230,000 received by other families. ${ }^{23}$ 
Teography of displacements can be generally identified. The majority of internally displaced people came from settlement schemes on the western borders of the Rift Valley, Uasin Gishu and Nandi districts, areas where agricultural employees live in Naivasha, Nakuru and Thika. The displaced people were small scale farmers, generally Kikuyu and Kamba, sometimes Kisii, who had settled for one or two generations, agricultural employees and junior Luo or Luhya civil servants settled in the dynamic areas in Central Province and eastern Rift Valley. All of them wanted to go back to their "villages of origin" or "ancestral land"-those from western Kenya even swore never to come back while holders of title deeds, mainly Kikuyu, very intent on coming back, to the land they now considered theirs. This situation led to a form of "Kikuyunisation" of the junior staff in the horticulture farms around Naivasha and in Central Province. Luo, Luhya and Kalenjin migrants in the farms were replaced by Kikuyu driven out of Maasai land, especially from Narok District to the south.

In Nairobi, during the weeks that followed the riots, tenants in populous residential areas (Kibera, Eastleigh, Mathare, Kangemi, Kawangware) were evicted by their landlords if they did not share the same ethnic identity. In the urban areas, social interaction led to ethnic and regional agreement between the tenants and the landlords at houses and residential estates. In the slums where the population is mixed, like in some parts of Mathare, gangs polarized space, leading to clear community fragmentation, with areas for Kikuyu or those from Central Province and neighbouring Kamba land and areas for the Luo or those from western Kenya.

31 Finally, a certain number of internally displaced people found refuge not in their "ancestral" land-which they sometimes only knew by name and where they were not always welcome-but in the Nairobi slums, which had to suffer under further congestion. There was therefore aggravation of urban poverty during the two months of crisis. Humanitarian actors unanimously agreed that this trend could persist and affect the urban landscape in the long-term. ${ }^{24}$

This spatial evolution towards increased space fragmentation at all levels is a demonstration of a brutal re-ethnicisation of social and territorial relations. The public space, ideally perceived as relatively neutral, has brutally receded, become fragmented and territorialized, in some cases to the extreme. The election and its mismanagement through rigging was sometimes simply the trigger for violence whose common denominator remains the classification and demonization of the other as the foreigner. 25 
Map 1: Leading candidates in the 2007 presidential elections

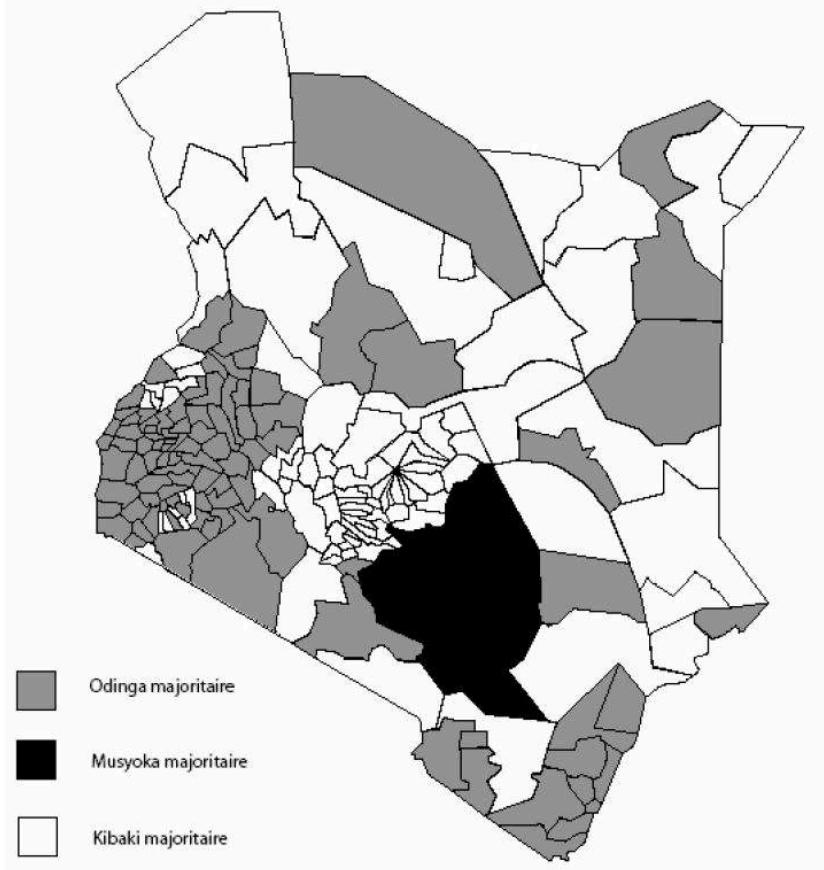

CANDIDAT ARRIVE EN TETE AUX ELECTIONS PRESIDENTIELLES DE 2007

Map 2: Results of the legislative elections of 27 December 2007

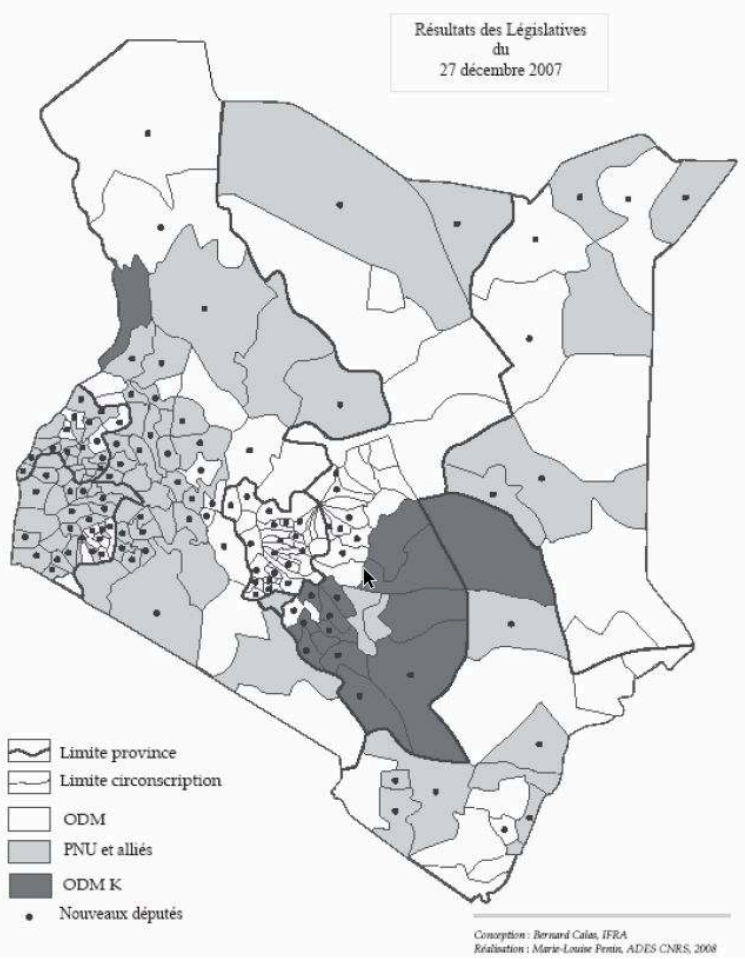

Conceived by Bernard Calas, IFRA; Produced by Marie-Louise Penin, ADES CNRS, 2008. 
Map 3: Rate of participation in the 2007 elections

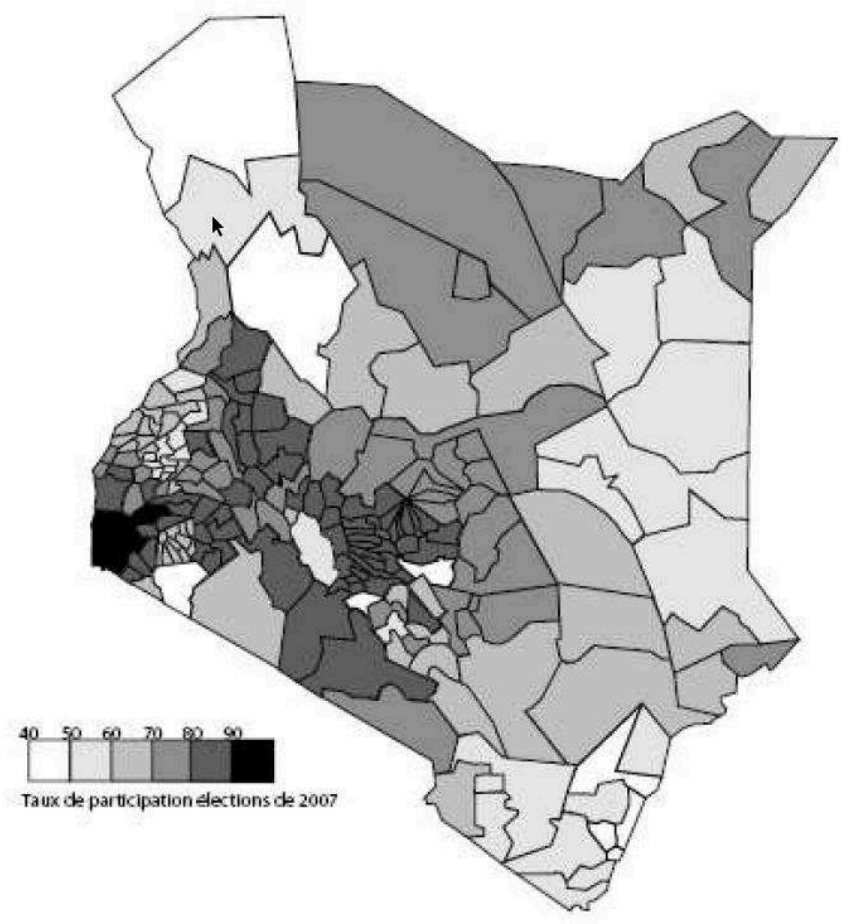

Conceived by Bernard Calas, IFRA; Produced by Marie-Louise Penin, ADES CNRS, 2008.

Map 4: constituencies with disputed results in the presidential elections, 30 December 2007

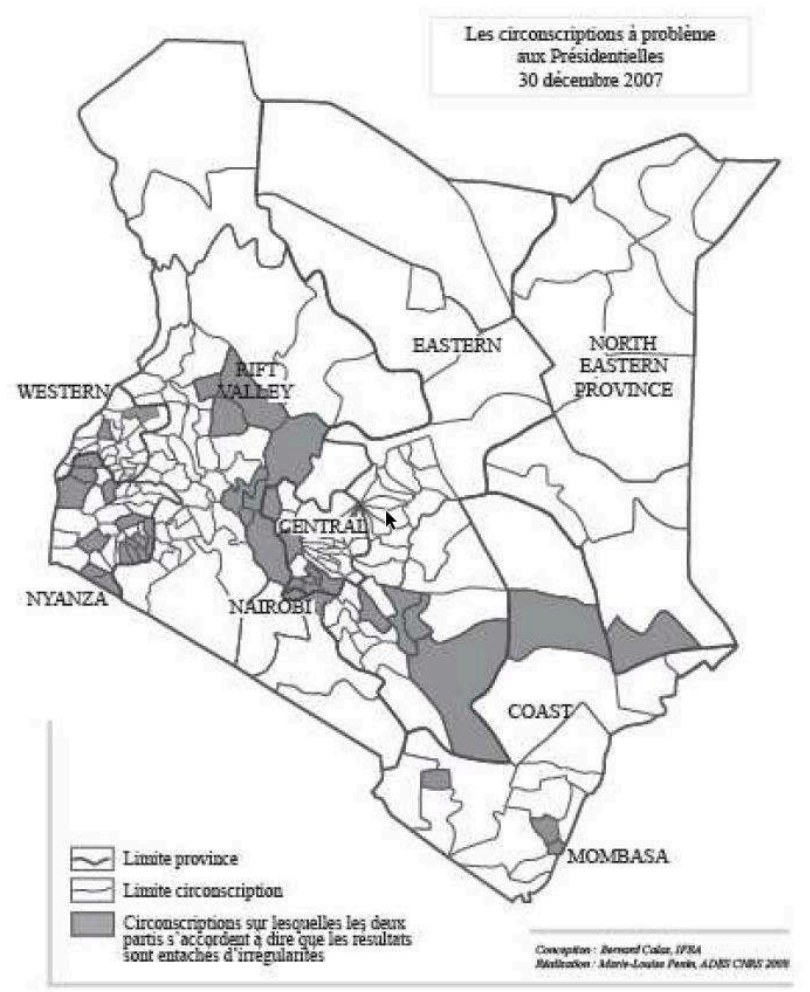

Conceived by Bernard Calas, IFRA; Produced by Marie-Louise Penin, ADES CNRS, 2008. 
Map 5: Kenya-an inverted land? A sketch of the violence experienced from 27 December 2007 to 28 February $2008<$

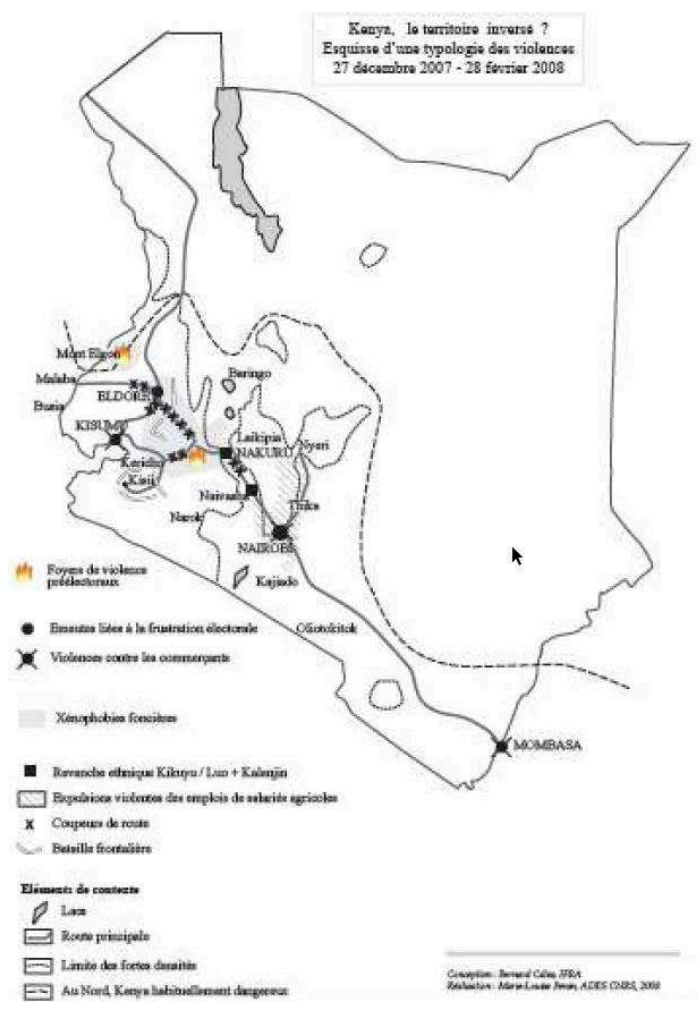

Map 6: An indication of electoral hegemony

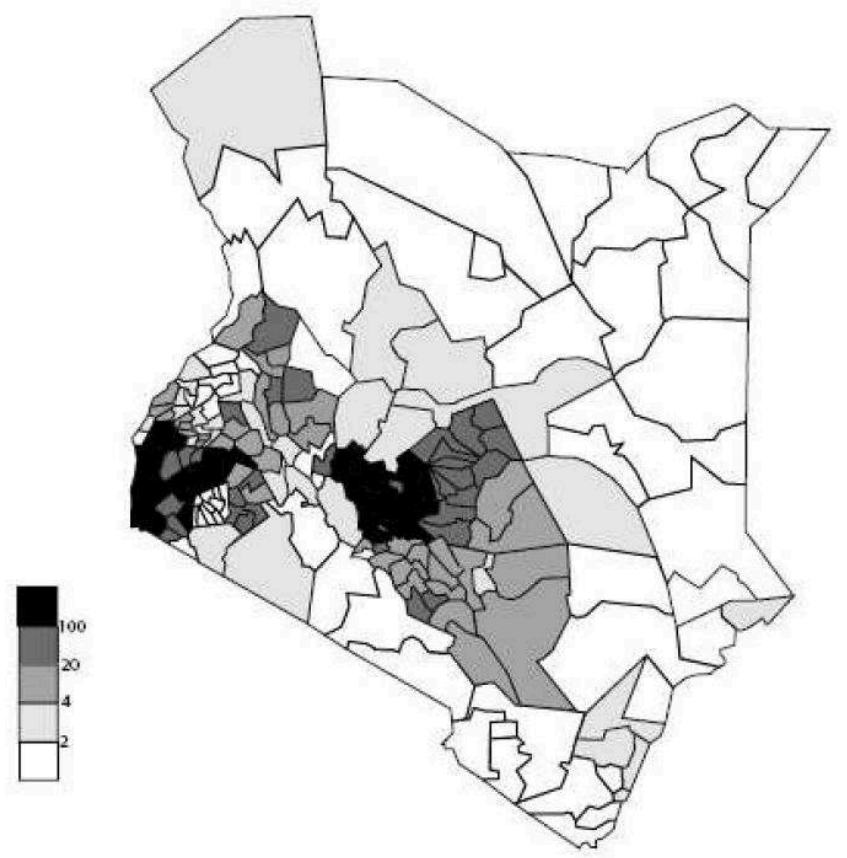

Indkateur d'hegemonie electorale

Taux par lequel II faut multiplis le nombre de voix du second candidat pour obtenir le nombre de volx du prember candidat

The rate by which the number of the votes obtained by the second candidate should be used to get the number of votes of the leading candidate. 


\section{NOTES}

1. This paper was written using information gathered from interviews and observations in Kenya, as events of the end of year 2007-2008 unfolded.

2. A. Oloo, 'Contested terrain: the politics of citizenship and constitutionalism in Kenya' and L. Maina, F. Waswa and S. Waiyego, 'Pitfalls in constitution-making in Kenya: experiences from Bomas and the 2005 national referendum.' In H. Charton and C. Médard (eds.), Annuaire de l'Afrique orientale 2005, Paris, l'Harmattan, 2007, pp. 59-101 and 103-127 respectively.

3. The voter registration exercise merits a whole paper on its own. Between 2002 and 2007, 4 million new voters were registered, which well over the natural increase in the number of voters. These were the fruits of good work by human rights NGOs and those working to promote democracy. The increase was mainly of young voters.

4. The Standard (Nairobi), 10 January 2008.

5. Refer to Kenya Elections Domestic Observation Forum, 'Preliminary statement and verdict of Kenya's 2007 general elections.' Nairobi, 31 December 2007. At a seminar organized by the British Institute in Eastern Africa at the premises of the Institut français de recherche en Afrique (Ifra), David Throup reaffirmed this supporting evidence.

6. Koki Muli, independent observer for the Institute for Education in Democracy, who was based at the KICC, personal statement, Nairobi, 30 December 2007.

7. An MP can change political party during one term without consulting his constituents. By so doing, he switches sides in the House and thus physically crosses the floor.

8. Refer to J. Oucho, Undercurrents of Ethnic Conflict in Kenya, Leiden, Brill, 2002, especially in pp. 132-170, as well as Claire Medard's paper in this collection.

9. Refer Y. Droz, Migrations Kikuyus, Des pratiques sociales à l'imaginaire, Neuchâtel, Institut d'ethnologie, Paris, Maison des sciences de l'homme, 1999.

10. Concerning majimbo, refer to P. Mutahi, 'Political violence in the elections.' In $\mathrm{H}$. Maupeu, M. Katumanga and W. Mitullah (eds.), The Moi Succession Election 2002, Nairobi, Transafrica Press, p. 70.

11. Refer to Anne Cussac's paper in this collection.

12. For mapping of the violence, refer to the Unosat web site, United Nations specialized agency for the handling of satellite images, www.unosat.org [archive], or Data exchange platform for the Horn of Africa web site, http://depha.org [archive]. On 4 January 2008, Unosat published a series of images of arson captured via satellite between 29 December 2007 and 2 January 2008 in the Rift Valley.

13. Human Rights Watch, Ballots and Bullets. Organized Political Violence and Kenya's Crisis of Governance, HRW report, vol. 20, No. 1, March 2008 [archive].

14. The tragedy took place on 1 January 2008. It was covered by all the media in the world and it caught many people's attention. Refer to Human Rights Watch, Ballots and Bullets... op.cit., p. 14. 
15. Concerning these issues, refer to P. Ndung'u, Report of the Commission of Inquiry into the Illegal/Irregular Allocation of Public Land, Nairobi, Government Printer, December 2004.

16. H. Maupeu, 'Mungiki et les élections. Les mutations d'un prophétisme kikuyu.' Politique Africaine, pp. 117-137 and 'Le rôle des institutions religieuses.' Cahiers de l'Afrique de l'Est, No 37, 2008, pp. 129-160.

17. Refer to International Crisis Group (ICG), Kenya in Crisis, Africa Report No 137, Nairobi, 21 February 2008.

18. On these two cases, refer to daily editions of Daily Nation and The Standard, Nairobi, 29 January 2007-2 February 2008.

19. In mid-January, Raila Odinga led delegations of international journalists, including $B B C$ journalists, in a visit to the Kisumu mortuary, with a view to showing them the bullet wounds on the bodies.

20. Concerning the issue of being native or outsider linked to majimbo, reference is made to Anne Cussac and Jérôme Lafargue in this collection.

21. For more on the economic consequences of the initial days of the crisis, refer to R. Porhel, 'The economic consequences of the political crisis,' in this volume.

22. This more aggressive term significantly replaced the term "checkpoints."

23. The Kenya Red Cross Society regularly updates its figures. Refer to www.kenyaredcross.org_[archive]

24. Round table of humanitarian actors at the French embassy in Nairobi, 19 February 2008.

25. For more on the subject of xenophobia, refer to C. Médard, in this volume.

\section{AUTHOR}

\section{BERNARD CALAS}

The author is the current director of IFRA and a professor of Geography. 